\title{
PROJECT IMPLEMENTATION PHASES AND PERFORMANCE OF AGRICULTURAL PROJECTS IN RWANDA A CASE OF N2AFRICA PROJECT/ CIAT IN KAMONYI DISTRICT
}

\author{
Ms. Alice Jeanne Marie UMUGWANEZA ${ }^{1 *}$, Sammy NYABERA ${ }^{2}$, Dr. Gitahi NJENGA ${ }^{3}$, \\ ${ }^{*}$ School of Business and Economics, Business Administration (MBA), \\ ${ }^{2,3}$ Project Management, Mount Kenya University, Kigali, Rwanda
}

*Corresponding Author: -

\begin{abstract}
: -
The project intended to determine the way project implementation phases signify the performance of N2Africa agricultural projects in Kamonyi District. Project aimed to establishing the influence of project planning on the performance of agricultural project, to determine the influence of project monitoring and evaluation on the performance of agricultural project and to explore how stakeholder involvement in project implementation influences agricultural project performance. The study applied descriptive cross-sectional case study design which applies both quantitative and qualitative methods and guided by the program theory and theory of change. Data was collected from 80 farmer beneficiaries, 8 N2Africa staff members and 2 Kamonyi District officials. Data analysis was conducted using SPSS software as a tool. Findings revealed that written project plan that indicate farm activity schedule were found to significantly impact project planning at N2Africa evidenced by a lower mean of 2.1875. The ability of project planning plan to indicate financial allocation to every project activity was found to significantly impact project performance mean of 2.1375. Project plan showing how risks will be mitigated was found to significantly impact project performance at N2Africa mean value of 2.4125. Upper relation between project planning and project performance of N2Africa was ascertained $(r=0.525, p<0.01)$. However, the results of a regression model revealed an insignificant association between project design and project advancement $(P=0.654) . M \& E$ had ability to promote dialogue among the project stakeholders mean 2.1625, monitoring and evaluation planning training mean 2.1625 , the strength of M\&E team mean 1.8500, compliance to Quality standards 2.4625and compliance to Activity2.1000 duration were found to significantly influence project performance. Occurs essential correlation between N2Africa scheme follow up and appraisal of its progress $\left(r=0.231^{*}, p<0.05\right)$. Regression analysis revealed that follow up, appraisal doesn't signify the progressive over N2Africa project $(P=0.896)$. Stakeholder involvement in project requirement analysis mean 2.1000, provision of expertise and wealth of knowledge mean 2.4750, removing and uncovering risks 2.2875 and determination work break down structure mean 2.1000significantly influenced the performance of N2Africa agriculture project. Have been also optimistic influential correlation between stakeholder involvement and project progress $\left(r=.267^{*}, p<0.05\right)$. The regression model revealed a significant association stakeholder involvement and performance of N2Africa project $(P=0.000)$. ANOVA results indicated that project implementation phases significantly influences project performance at $N 2 A$ frica $(P=0.000)$. The study concluded that project implementation phases influence project performance and the study therefore recommended that project implementation phases should be handled carefully since they affect the overall performance of the project.
\end{abstract}

Keywords: - Project implementation, Project Performance, N2Africa Project

\section{(a) $(\$)$}




\section{INTRODUCTION}

Project implementation phase is one of the longest phases in project management as it consumes most of the energy and time. At this phase, risk, time, resources quality and other issues are managed to ensure the project is successfully implemented (Al-Agele \& Ali, 2017). The project implementation phase helps to accomplish the activities described in the project management plan which leads to project success (Lencucha et al., 2020). The studies conducted in this field of project implementation and performance has given less attention, the contribution of project implementation on the performance of agricultural project. Though, it seems ineffective project implementation strategies hinders the performance of the project and as well bringing a number of challenges to the project.

The study of Zwickau and Smyrk (2019) has revealed that there are various challenges faced while managing project implementation and some of these challenges are; incapacity of the project to secure required resource, overlapping sources of ideas, poor project planning, poor budgeting, delayed cash disbursement by clients, low skill of the project manager, lack of monitoring and evaluation experts and low stakeholder engagement. Failure to identify and manage these challenges leads to project failure and despite the existence of these challenges and their impact on project success, no study has evaluated these challenges and made suggests on how to overcome them. Therefore, it is against this background that the project determines the impact of project planning, monitoring and evaluation and stakeholder engagement on performance of N2Africa in Kamonyi District Rwanda.

\subsection{Objectives of the study \\ 1.1.1 General objective}

The main objective of this research was to ascertain the influence of project implementation phases on performance of N2Africa agricultural project in Kamonyi District Rwanda.

\subsubsection{Specific objectives}

(i) To establish the influence of project planning on the performance of N2 Africa agricultural project in Kamonyi District, Rwanda

(ii) To determine the influence of project monitoring and evaluation on performance of N2 Africa agricultural project in Kamonyi District, Rwanda

(iii) To explore how stakeholder involvement in project implementation influences project performance of N2 Africa agricultural project in Kamonyi District, Rwanda.

\section{Review of Literature}

\subsection{Project planning and project performance}

Globally it has been revealed that project planning input factors affect project performance (Hamrd, 2016) and it was estimated that about $38 \%$ of global project fail due to poor scheme design phase. Project failure was estimated to cost the European Union countries 142 billion per year in 2012 (Mcmanus \& Wood-harper, 2018). In the study conducted in Pakistan exploring how project planning affect project success mediated by with mediating role of risk management and moderating the impact of executive customs regressions and correlations indicated a significant correlation between designing of project and organizational advancement (Naeem et al., 2018) and the study concluded that project planning influences project success and recommended for more focus on planning phase during project implementation. A study conducted by Tesfaye et al., (2017) in USA findings revealed that project planning procedures are very impervious to man's issues and project cost, time and threats being linked with performance of the project. The study concluded that in order to have project success project planning procedures must be given attention and it was recommended that project managers should focus on initial stages of project planning.

About $47 \%$ of sub-Saharan African project failures have been attributed to poor project planning practices as most projects have been reported to fail. In Ghana project planning process was found to significantly impact project performance (Amponsah, 2012). A study by Gbahabo and Ajuwon, (2017) conducted about effects of project cost and delays on project performance revealed that project expenditure and schedules delay in roads procurement processes can have detrimental effects on utilization of resources. the study concluded that project procurement processes should be streamlined. In Nigeria, Adeyemi, (2013) results revealed that project planning had a significant relationship with project quality, success and technical success. The study concluded that project planning must be number one phase undertaken to enable any project to succeed and it was recommended that project managers should majorly focus on this phase.

The study conducted in Kenya by Amadi, (2017) revealed the planning of projects, evaluation and monitoring, effective communication and engagement of stakeholders possessed a significant association with community livelihood improvement programs. The research conducted in Nairobi City County by Muute, (2019) results indicated that the planning of human resources, management of project time and resource utilization contributed significantly to the success of construction projects. In Northern Uganda, Project Manager Competence, community involvement, coordination and effective project implementation influence project performance $(r=0.70, p<0.01 \& r=0.57 p<0.01)$ respectively. In Rwanda, Shukla, (2015) revealed that human resource and financial planning were found to affect the performance of Agaseke project. In summary the reviewed studies have concentrated on agricultural project and specifically on N2Africa project hence the validity of this research. 


\subsection{Project monitoring and evaluation and project performance}

Various studies have indeed indicated that monitoring and evaluation function significantly impact project performance (Ocharo, 2020; and Waithera, 2015). For example, in Cuba, Activities such as monitoring and evaluation planning before project initiation and performance, indicator identification have been emphasized in order to have the required project results (Abarinda, 2019). The correlation results revealed to signify the correlation between follow up and estimation of project progress 0.8 in Kenya (Phiri, 2015). In Ghana, (Ocharo, 2020) study indicated $\mathrm{m}$ and practices are essentially related over success of construction projects and in Uganda (Abarinda, 2019) research revealed that monitoring and evaluation planning and training had a significant correlation with project performance of $0.92,0.725$ and 0.622 correspondingly.

The study conducted in Nakuru, Kenya, by Winch et al., (2010) examined the relationship between project performance and monitoring and evaluation considering agribusiness project results indicated a significant relationship between the dependent and the independent variables. The study concluded that monitoring and evaluation plays a significant role through cost and budget management. The research conducted in Rwanda by Sheillah, (2020), revealed that possession of $M \& E$ does not guarantee project success. The findings further indicated that M\&E frameworks have a significant correlation with success of projects in agriculture, Spearman's correlation coefficient of 0.511 and Monitoring and evaluation information sharing and utilization Spearman's correlation coefficient of 0.476 were found to significantly influence project performance (Shukla, 2015). In summary some studies have indicated how M\&E affects project performance even in the agribusiness sector and some have been done in Rwanda.

Naeem, et al., (2018) opined that project plans are normally made in workplace away from places where projects are to be situated and away from people who will be affected by project activities and procedures laid out in the project planning handbooks are usually applied rigidly. However, the study fails to show the extent to which project managers are working to include farmers as stakeholders in the planning processes of projects.

\subsection{Stakeholder involvement and project performance}

Stakeholder involvement in performance of development projects cannot be ignored for example in United Kingdom a study conducted to determine the role of stakeholder on development project revealed that stakeholders are involved project identification, planning, implementation and monitoring which are critical steps in project success (Magassouba et al., 2019). In turkey, findings indicated that engagement of stakeholders in planning significantly influence performance of automobile projects (Njogu, 2016). In Australia, stakeholders were found to provide the required resources and ability required for the survival of building projects (Heravi et al., 2015).

A study Klijn, (2019) conducted on the role of stakeholder in public- private partnership projects in sub-Saharan Africa findings indicated that stakeholders promote engagement of communities' groups and promote innovation but does not essentially lead to improved project outcomes. A multi-stakeholder student involvement study project results revealed that the involvement of state and society as stakeholders significantly impacted the performance of these projects.

A study conducted in Nigeria by Vaquero et al., (2021) regarding the predicament of stakeholders in product market development projects (NPD) it was found out that stakeholder involvement significantly impacts new product development projects financial performance and lead to low efficiency in new product development processes. It was concluded that to have the best product which will attract customers will require the use of stakeholder knowledge in any stage of development. Furthermore, a study conducted to quantify the effect of nontraditional involvement of stakeholders in architectural projects, results were statistically significantly linked to development in 3 varying measurements and these were information requests, improvement in project quality and speed of delivery speed. Stakeholder involvement in mining projects was found to significantly impact their performance; the stakeholders here were financial partners and market researchers. A Ugandan study found the influential correlation between involvement over organizational stakeholders plus progress of poverty eradication projects (Hassan, 2010). These projects reviewed here few are on agriculture except (Hassan, 2010).

\section{Materials and Methods}

The researcher employed a cross-sectional descriptive case study plan was deployed to carry out this study. Questionnaires and interviews were adopted in the of data collection process signifying the use of qualitative and quantitative approaches. The study population included 102 beneficiaries of N2Africa project, 10 staff members of N2Africa project and 2 Kamonyi District staff members. Therefore, to select the number of the respondents the formula of Krejce and Morgan (1970) was preferred to have a sample of 90 respondents. The researcher administered a questionnaire to 8 N2Africa beneficiaries while the 10 respondents of the study were given interview.

Qualitative data were analyzed thematically and content analysis to understand the impact of project implementation on project performance. Whereas, SPSS 21 was used to analyze the quantitative data.

Expressive and inferential statistics such as association applied to investigate this data. Mean and standard deviations were generated to attach meaning to the study variables. To form the environment and magnitude of the relations between the variables and to test the hypothesized association regression investigate and correlation analysis was performed.

The research was presented using graphs, and tables which enabled the researcher to meaningfully describe the distribution of scores and measurements, the research also shared the findings with the management of N2 Africa agricultural Project for their comments and guidance in data analysis, using these techniques the presentation, analysis and interpretation of the findings were easy to comprehend. A linear regression model was fitted to measure the association between the dependent and independent variables of the research as described below. Where $\mathrm{Y}=$ performance 
of N2Africa agricultural project in Rwanda. B0 model constant, B1 $-\beta \mathrm{n}=$ Coefficients of the regression model, $\mathrm{X} 1$ is project planning, $\mathrm{X} 2$ is project monitoring and evaluation and $\mathrm{X} 3$ is stakeholder involvement, while $\varepsilon=$ Error term.

\subsection{Influence of project planning on the performance of $\mathrm{N} 2$ Africa agricultural project}

Table 4.1: Descriptive statistics

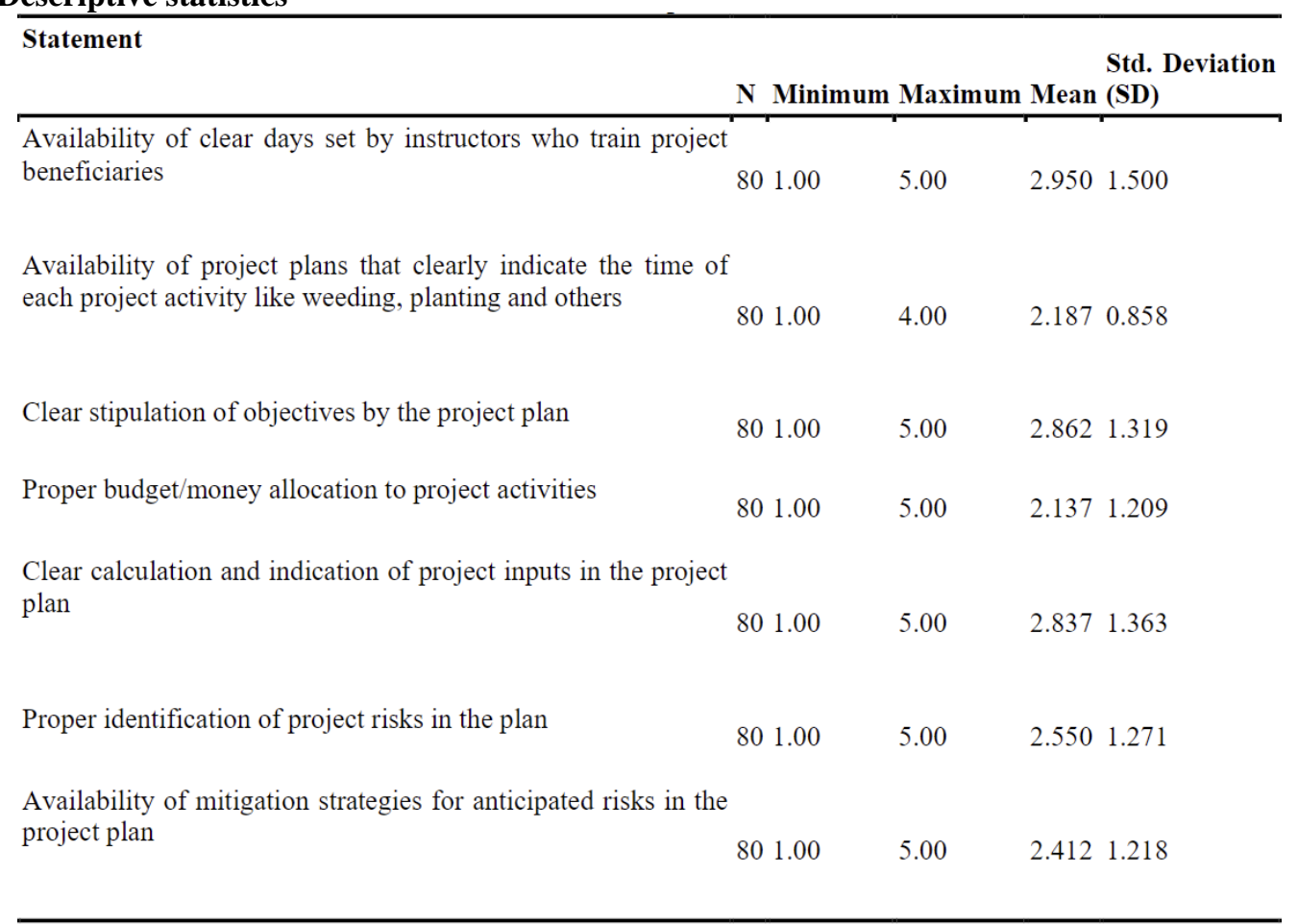

Mean $<2.5$ significant and Mean $\geq 2.5$ insignificant

The results in the Table 4.1 are based on a five point Likert scale where $1=$ strongly agree, $2=$ agree, $3=$ neutral, $4=$ disagree, and $5=$ strongly disagree. The results showed that project planning in terms of availability of clear days set by instructors who train project beneficiaries has significantly influenced the performance of N2Africa project evidence by a higher mean of 2.950 which in the scale of insignificancy according to (Chakrabartty, 2019) scale and SD of 1.500 that is high reveals that the data is clustered around the mean which shows further confirmation of the insignificancy of the factor. Project plans that clearly indicate the time of each project activity like weeding, planting and others were found to significantly impact project planning at N2Africa evidenced by a lower mean of 2.1875 according to (Chakrabartty, 2019) scale and lower standard deviation of 0.858 that indicates that data is scattered away from the mean which further confirms the significance of the factor.

Furthermore, findings in table 4.1 showed that project having a plan which has clear objectives significantly did not significantly impact project performance at N2Africa agricultural project as evidenced by a higher mean of 2.862 beyond the scale suggested by (Chakrabartty, 2019). The SD of 1.31922 was moderately high showing that data was more spread out along the mean which further shows insignificance. As the data spreads out the mean it tends to the directions of neutral disagree and strongly disagree which are represented by high values of 3,4, and five on the Likert scale used but if it clusters around the mean it is tending towards the directions of agree and strongly are which are represented by values 1 and 2.

Proper budget/money allocation to project activities was found to significantly impact project performance since mean of 2.137 is in the significance scale and SD is small that reconfirms the significance of the factor. Furthermore, clear calculation and indication of project inputs in the project plan was found to insignificantly impact project performance evidenced by a higher average/mean of 2.837 and SD of 1.363. Proper identification of project risks in the plan was found to insignificantly impact project performance at N2Africa evidenced by a higher mean value of 2.550 and a SD of 1.271 showing that data is spread out of the mean and finally the monitoring plan showing how risks will be mitigated was found to significantly impact project performance at N2Africa evidenced by a lower mean value of 2.412 and SD of 1.218 .

According to qualitative information obtained from the focus group discussion (FGD) conducted with 8 staff members of N2Africa project it was narrated as follows;" before any successful project begins, a project plan must first be designed because this project plan is the one that shows the complete roadmap for achievement of the project success and such things considered in the project are; clear statement of the goals and objectives, activities to be undertaken, project inputs and outputs, implementation plan, risk assessment budget among others. If all these are planned before the commencement of the project, there is no way how a project can fail"

These findings agree with some of the statement in the descriptive statistics such proper identification of project risks in the plan was found to possess a significant mean on the success of the project and the results of the correlation findings also agree with these qualitative results by showing that project planning significantly affects project performance. One 
of the officers' form Kamonyi District also narrated as follows; "project planning is the heart of any intervention let it be profit making or nonprofits because it lays a framework for the start and end of the project. It describes all, resources, skills and finances required for project performance." However these interview findings are general compared to findings from FGD, descriptive statistics and correlation analysis and I can easily deduce that they are in contradiction

Table 4.2: Correlation analysis of the influence of project planning on the performance of N2 Africa agricultural project

\begin{tabular}{llll}
\hline Matrix & & Project performance & Project planning \\
\hline project performance & Pearson Correlation & 1 & $.511^{* *}$ \\
& Sig. (2-tailed) & & .000 \\
& $\mathrm{~N}$ & 80 & 80 \\
project planning & Pearson Correlation & $.511^{* *}$ & 1 \\
& Sig. (2-tailed) & .000 & 80 \\
\hline
\end{tabular}

**. Correlation is significant at the 0.01 level (2-tailed).

Table 4.2 indicate that project planning is significantly correlated to project performance of agriculture project $\quad(\mathrm{r}=0.525$, $\mathrm{p}<0.01)$. There was strong correlation between project planning in N2 Africa Rwanda and performance of agriculture project.

4.2. Influence of project monitoring and evaluation on the progress of $\mathrm{N} 2$ Africa agricultural project Table 4.3: Influence of monitoring and evaluation on the performance of N2Africa

\begin{tabular}{|c|c|c|c|c|}
\hline Statement & Minimum & Maximum & Mean & $\begin{array}{l}\text { Std. } \\
\text { Deviation }\end{array}$ \\
\hline $\begin{array}{l}\text { M\&E influences project performance through } 80 \\
\text { needs assessment }\end{array}$ & 1.00 & 5.00 & 3.5375 & 2.46979 \\
\hline $\begin{array}{l}\text { M \& E promotes dialogue among the project } 80 \\
\text { stakeholders }\end{array}$ & 1.00 & 5.00 & 2.1625 & 1.18475 \\
\hline $\begin{array}{l}\text { M\& E promotes participation of stakeholders in } 80 \\
\text { the project }\end{array}$ & 1.00 & 5.00 & 3.9875 & 1.14177 \\
\hline $\begin{array}{l}\text { Monitoring and evaluation planning training } 80 \\
\text { influences project performance }\end{array}$ & 1.00 & 3.00 & 1.8500 & .61829 \\
\hline $\begin{array}{l}\text { The strength of } \mathrm{M} \& \mathrm{E} \text { team influences project } 80 \\
\text { performance }\end{array}$ & 1.00 & 5.00 & 2.4625 & 1.25228 \\
\hline $\begin{array}{l}\text { Baseline surveys in monitoring and evaluation } 80 \\
\text { influences project success }\end{array}$ & 1.00 & 5.00 & 2.7375 & 1.29012 \\
\hline $\begin{array}{l}\text { Compliance to Quality standards influence project } 80 \\
\text { performance }\end{array}$ & 1.00 & 4.00 & 1.6625 & .77857 \\
\hline $\begin{array}{l}\text { Compliance to activity cost influence the } 80 \\
\text { performance of the project }\end{array}$ & 1.00 & 5.00 & 2.8375 & 1.36357 \\
\hline $\begin{array}{l}\text { Compliance to Activity duration also influences } 80 \\
\text { project performance }\end{array}$ & 1.00 & 5.00 & 2.1000 & .94935 \\
\hline $\begin{array}{l}\text { The organization conducts monthly projects } 80 \\
\text { appraisals influences performance }\end{array}$ & 1.00 & 5.00 & 2.9000 & 1.27884 \\
\hline
\end{tabular}

Mean $<2.5$ significant and Mean $\geq 2.5$ insignificant

The results in table 4.3 revealed that $\mathrm{M} \& \mathrm{E}$ does not significantly influence project performance in terms needs assessment as well as their expressions evidenced by a higher mean of 3.5375 and a SD of 2.46979 indicating that data is completely spread out away from the mean further confirming the insignificance of the factor on project performance. Results further indicated that $\mathrm{M} \& \mathrm{E}$ ability to promote dialogue among the project stakeholders was found to significantly influence project performance evidenced low average value of 2.1625 and a SD of 1.18475 indicating that M\&E significantly influences project performance. Results indicated that M\& E does not promote participation of stakeholders in the project evidenced by a higher insignificant mean value of 3.9875 and a standard deviation of 1.14177 indicating that data is not spread away from the mean. M\&E training was found to significantly influence performance evidenced by a lower significant mean of 1.8500 in accordance with (Chakrabartty, 2019)and a low standard deviation of 0.61829. Furthermore, results have revealed that the strength of M\&E team significantly influence the performance of N2Africa project 
evidenced by a low mean value of 2.4625 less than 2.5 according to (Chakrabartty, 2019)and a standard deviation of 1.25228

However baseline surveys in M\&E were found to insignificantly influence project performance of N2Africa evidenced by higher mean value of 2.7375 and standard deviation of 1.25228. Compliance to Quality standards was found to significantly influence project performance mean 1.6625 and standard deviation of 0.77857 . Compliance to activity cost does not impact /influence the performance of the project in N2Africa means 2.8375 and standard deviation 1.36357. Then compliance to Activity duration was found to significantly influence project performance evidenced by a low mean value of 2.1000 and standard deviation of .94935 . Finally organization monthly projects appraisals were found not to significantly influence project performance mean 2.9000 and standard deviation 1.27884.

In FGD with the staff member of N2Africa project, the major findings revealed from different participant were; "Monitoring and evaluation practices such as schedule monitoring, project cost monitoring, scope monitoring were explained to affect project performance. Participants further explained collecting information to track the progress of the project helps to identify faults early such that they fixed so that the project can succeed. They further mentioned that comparing the completed activities with the expected results which is part of the evaluation exercise also helps to prevent production of substandard results and aids in attainment of quality and quantity in project implementation"

In an interview with one of the Kamonyi District officers, it was stated as follows; " all community development projects need monitoring and evaluation plan to perform up to the expected results for example monitoring and evaluation informs the stakeholders what is right and what is wrong with the project implementation exercise such that the mistakes can be corrected early. Monitoring and evaluation helps project stakeholders to align the project to its objectives hence achievement of project performance"

Table 4.4: Correlation analysis relating M\&E and N2 Africa agricultural project performance

\begin{tabular}{|c|c|c|c|}
\hline \multicolumn{2}{|l|}{ Correlation matrix } & \multirow{3}{*}{ Project performance } & \multirow{3}{*}{$\begin{array}{ll}\begin{array}{l}\text { Monitoring } \\
\text { evaluation }\end{array} \\
.231^{*}\end{array}$} \\
\hline & & & \\
\hline Progressive of the project & Pearson Corr. (r) & & \\
\hline & Sig. (2-tailed) & & .039 \\
\hline & $\mathrm{N}$ & 80 & 80 \\
\hline \multirow[t]{3}{*}{ monitoring and evaluation } & Pearson Corr. (r) & $.231^{*}$ & 1 \\
\hline & Sig. (2-tailed) & .039 & \\
\hline & $\mathrm{N}$ & 80 & 80 \\
\hline
\end{tabular}

The Table 4.4 shows the correlation analysis results between M\&E and performance of N2Africa project which is significantly correlated to performance of agriculture project $\left(\mathrm{r}=.231^{*}, \mathrm{p}<0.05\right)$. There was a positive and significant correlation between project monitoring and evaluation in N2 Africa Rwanda and performance of agriculture project.

\begin{tabular}{|c|c|c|c|c|}
\hline Statement & Minimum & Maximum & Mean & $\begin{array}{l}\text { Std. } \\
\text { Deviation }\end{array}$ \\
\hline $\begin{array}{l}\text { Stakeholders have played a significant role in project } \\
\text { scope determination and management }\end{array}$ & 1.00 & 5.00 & 2.8125 & 1.28372 \\
\hline Stakeholders have helped in project requirement analysis 80 & 1.00 & 5.00 & 2.1000 & .89443 \\
\hline $\begin{array}{l}\text { Stakeholders of are important in schedule determination } 80 \\
\text { and management }\end{array}$ & 1.00 & 5.00 & 2.7250 & 1.25259 \\
\hline $\begin{array}{l}\text { Stakeholders are providing expertise and wealth of } 80 \\
\text { knowledge on the project }\end{array}$ & 1.00 & 5.00 & 2.4750 & 1.11350 \\
\hline $\begin{array}{l}\text { The stakeholders are removing and uncovering risks on } 80 \\
\text { the project }\end{array}$ & 1.00 & 5.00 & 2.2875 & 1.11598 \\
\hline $\begin{array}{l}\text { Stakeholders help in work break down structure when } \\
\text { they are involved at project in initiation stage }\end{array}$ & 1.00 & 5.00 & 2.1000 & .94935 \\
\hline
\end{tabular}

Mean $<2.5$ significant and Mean $\geq 2.5$ insignificant

The results in Table 4.5 indicate that stakeholders have not played a significant role in project scope determination and management during the struggle for project success evidenced by a higher mean 2.8125 according to (Chakrabartty, 2019)level and a high SD of 1.28372. This implies that data is more spread out about the mean hence the factor not significant. Results further indicated that stakeholders have helped in project requirement analysis at N2Africa evidenced by a lower significant mean according to (Chakrabartty, 2019) scale and a very low SD of 0.89443 implying that data is concerted towards the mean hence significant. It was again revealed that stakeholders are not important in schedule determination and management evidenced by a higher average of 2.7250 and a SD of 1.25259. Stakeholders' provision of expertise and wealth of knowledge on the project was found to significantly influence project success evidenced by a 
mean of 2.4750 and a standard deviation of 1.11350, also there role in removing and uncovering risks on the project could not be underestimated approved by low average of 2.2875 and a SD of 2.2875 and finally were found to significantly help in work break down structure when they are involved at project in initiation stage mean 2.1000 and standard deviation 0.94935

In a FGD with 8 staff members of N2Africa, it was narrated; "Stakeholder engaged meant in a project is so crucial since stakeholders are master planners of the project, they plan and implement the project and therefore crucial for project performance". However the information from interviews with Kamonyi District officers was similar and they reported that; " a stakeholder in project implementation can either be an individual or organization involved in the running of the project activities and may be affected positively or negatively as a result of successful project execution. Stakeholders work antagonistically to achieve project performance"

Table 4.6: Correlation analysis of the essential of stakeholder participation on the progressive of N2 Africa agricultural project

\begin{tabular}{cccc}
\hline & & $\begin{array}{c}\text { Stakeholders } \\
\text { involvement }\end{array}$ & $\begin{array}{c}\text { Project } \\
\text { performance }\end{array}$ \\
Stakeholder involvement & Pearson Corr (r) & 1 & $.267^{*}$ \\
& Sig. (2-tailed) & & .017 \\
Project performance & $\mathrm{N}$ & 79 & 79 \\
& Pearson Corr (r) & $.267^{*}$ & 1 \\
\hline Sig. (2-tailed) & $\mathrm{N}$ & .017 & 80 \\
\hline
\end{tabular}

*. $r$ significant when $\mathrm{P}=0.05$ level

The Table 4.6 indicates correlation analysis results relating stakeholder engagement and performance of N2Africa project which is significantly correlated as $\left(r=.267^{*}, \mathrm{p}<0.05\right)$. Thus, it implies that there a positive and significant correlation between stakeholder involvement in N2 Africa Rwanda and performance of agriculture project.

Table 4.7: Performance management of N2Africa project

\begin{tabular}{|c|c|c|c|c|c|}
\hline Statement & $\mathbf{N}$ & Minimum & Maximum & Mean & $\begin{array}{l}\text { Std. } \\
\text { Deviation }\end{array}$ \\
\hline $\begin{array}{l}\text { Clients/ farmer beneficiaries were satisfied with the } \\
\text { project activities }\end{array}$ & 80 & 1.00 & 5.00 & 2.6127 & 1.25171 \\
\hline The project always managed its schedule of activities e & 80 & 1.00 & 5.00 & 2.3040 & 1.09443 \\
\hline Project activities were profitable to farmers & 80 & 1.00 & 5.00 & 2.9250 & 1.14252 \\
\hline $\begin{array}{l}\text { Cost of accessing the project benefits were favorable and } \\
\text { the project always managed its funds }\end{array}$ & & 1.00 & 5.00 & 2.7250 & 1.12354 \\
\hline
\end{tabular}

The results in Table 4.7 on Performance of N2Africa project was measured in terms of four (4) categories and these are; satisfaction, schedule management, profitability and cost management, and these results revealed that the famers were significantly satisfied with N2Africa project evidenced by a higher mean of 2.6127; respondents further revealed that Project activities were profitable to farmers evidenced by a higher mean of 2.9250 and finally respondents reported the Cost of accessing the project benefits were favorable and the project always managed its funds evidenced by a significant mean of 2.7250

Table 4.8: Regression coefficients

\begin{tabular}{|c|c|c|c|c|c|}
\hline \multirow[b]{2}{*}{ Predictors } & \multicolumn{2}{|c|}{ Uns. coeff } & \multirow{2}{*}{$-\frac{\text { Stand. coeff }}{\text { Beta }}$} & \multirow[b]{2}{*}{$\mathbf{t}$} & \multirow[b]{2}{*}{ P. } \\
\hline & $\mathrm{B}$ & Std. Error & & & \\
\hline (Constant) & .946 & .382 & & 2.479 & .015 \\
\hline Project planning & .035 & .077 & .048 & .450 & .654 \\
\hline Monitoring and evaluation & -.006 & .043 & -.015 & -.131 & .896 \\
\hline Stakeholder involvement & .382 & .086 & .517 & 4.454 & .000 \\
\hline
\end{tabular}

Dependent variable: Project performance

Table 4.8 indicates coefficients of the independent variables applied in research project. The finding showed that the project planning unstandardized B coefficient of 0.035 . This means that for each one unit increase in project planning, project performance increases by 0.035 units assuming monitoring and evaluation and stakeholder involvement are kept constant. The findings further showed that project planning alone causes $4.8 \%$ variation in project performance when monitoring and evaluation and stakeholder are kept constant. The P> $0.05(0.654)$ further reconfirming that the there is no significant impact of project planning on project performance. Therefore, we accept the null hypothesis. Furthermore, in Table 4.12 finding showed that M\&E unstandardized B coefficient is -0.006 . This means that for each one unit increase 
in follow up, and appraisal of organization progress, reduces by -0.006 units assuming scheme designing, follow up and appraisal the stakeholder involvement are kept constant.

The results further showed that monitoring and evaluation alone causes $4.3 \%$ variation in project performance when project planning and stakeholder involvement are kept constant. The P> $0.05(0.896)$ further reconfirming that the there is no significant impact of $\mathrm{M} \& \mathrm{E}$ on project performance. Therefore, we accept the null hypothesis. Furthermore, in Table 4.12 finding showed that stakeholder involvement unstandardized B coefficient is 0.382 . This means that for each one unit increase in stakeholder involvement, project performance increases by 0.382 units assuming project planning and monitoring and evaluation are kept constant. The findings further showed that stakeholder involvement alone causes $51.7 \%$ variation in project performance when project planning and monitoring and evaluation are kept constant. The $\mathrm{P}<0.05$ (0.000) further reconfirming that the there is a significant impact of monitoring and evaluation on project performance. Therefore, we reject the null hypothesis.

\subsection{Conclusion}

The first objective was to determine the influence of project planning on the performance of N2 Africa agricultural project however correlation analysis indicated a significant positive relationship between project planning and project performance but multiple regression model showed an insignificant relationship between project planning and project performance. The second objective sought to determine the influence of monitoring and evaluation on project performance, application of correlation indicated a significant relationship between M\&E and project performance while multiple regression models revealed an insignificant relationship.

The last objective was to determine the influence of stakeholder engagement on performance of N2Africa agricultural project in Kamonyi. There was a strong positive correlation between stakeholder involvement and project performance. Multiple regression models also revealed a strong significant relationship between stakeholder involvement and project performance. ANOVA results indicated that project implantation significantly influences project performance at N2Africa $(\mathrm{P}=0.000)$.

\subsection{Acknowledgement}

Many people have added to the achievement of this project but most importantly, the lord almighty. The finishing of this dissertation should not have happened with no the input and support of wide range of individuals whose names cannot be acknowledged all in this project. Their support is really recognized and felt. However, I want also to articulate my acknowledgement to staff of N2Africa project, Kamonyi District staff members and farmers who are the beneficiaries of N2 Africa project. I also appreciated my family, for the love, care and invaluable support through my whole studies and this research in particular. To everyone including family, associates and who have supported me in one way or the other, I say thank you.

\section{References}

[1].Abarinda. (2019). Towards improving schedule performance of construction projects in Uganda with lean construction. University of Leeds, 1(3), 658-667.

[2].Adeyemi, I. (2013). Effects of Project Management on the Performance of a Construction Firm in Nigeria. American International Journal of Contemporary Research, 3(6), 54-58.

[3].Al-Agele, D. H. K., \& Ali, A. J. (2017). Mismanagement Reasons of the Projects Execution Phase. Journal of Engineering, 23(April), 15-29.

[4].Amadi, J. O. (2017). The Role of Planning on Performance of Community Projects in Kenya. Developing Country Studies, 7(1), 1-7.

[5].Amponsah, J. (2012). The Real Project Failure Factors and the Effect of Culture on Project Management in Ghana By Ghana Institute of Management and Public Administration ( Gimpa ) Accra , Ghana. Amponsah, 5(2), 45-56.

[6].Chakrabartty, S. N. (2019). Scoring and Analysis of Likert Scale: Few Approaches. Journal of Knowledge Management and Information Technology, 1(2), 31-44.

[7].Hamrd. (2016). critical factors that lead to project success/failure in global market place. 9th International

[8].Conference Interdisciplinarity in Engineering Romania, $22(1), \quad 1066-1075$. https://doi.org/10.1016/j.protcy.2016.01.151

[9].Magassouba, S. M., Malek, A., Tambi, B. A., Alkhlaifat, B. I., Aziz, A., \& Abdullah, B. (2019). Influence of Stakeholders Involvement on Development Project Performance in Guinea. International Journal of

[10]. Academic Research in Business and Social Sciences, 9(1), 1111-1120. https://doi.org/10.6007/IJARBSS/v9-i1/5513

[11]. Ocharo. (2020). Influence of monitoring and evaluation frameworks on performance of public agricultural projects in.European Journal of Physical and Agricultural Sciences, 8(1), 1-10.

[12]. Phiri, B. (2015). Influence Of Monitoring And Evaluation On Project Performance: A Case Of African Virtual University, Kenya. Un Published Masters Thesis Nairobi University, 2(2), 78-82.

[13]. Sheillah, N. D. (2020). Project Planning and Project Success in Local Government of Rwanda. International Journal of Scientific and Research Publications (IJSRP), 10(06), 457-464. https://doi.org/10.29322/ijsrp.10.06.2020.p10254

[14]. Shukla, K. (2015). Effects Of Project Resource Planning Practices On Project Performance Of Agaseke Project In Kigali, Rwanda. International Journal of Business and Management Review, 3(5), 29-51. 
[15]. Tesfaye, E., Lemma, T., Berhan, E., \& Beshah, B. (2017). Key project planning processes affecting project success Key Project Planning Processes. International Journal for Quality Research, 11(1), $159-172$. https://doi.org/10.18421/IJQR11.01-10

[16]. Vaquero, M., Reinhardt, R., \& Gurtner, S. (2021). The dilemma of downstream market stakeholder involvement in NPD : Untangling the effects of involvement and capabilities on performance. Journal of Business Research, 124(2), 136-151. https://doi.org/10.1016/j.jbusres.2020.11.040

[17]. Waithera, S. L. (2015). Influence Of Project Monitoring And Evaluation On Performance Of Youth Funded Agribusiness Projects In Bahati Sub-County, Nakuru, Kenya. International Journal of Economics, Commerce and Management, III(11), 375-394. 